\title{
The effect of foliar fertilizing on ecological optimization of the application of fungicides on the productivity and phenolic complex composition of grapes
}

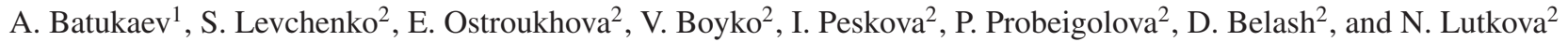 \\ ${ }^{1}$ Chechen State University Grozny, Russian Federation \\ ${ }^{2}$ All-Russian National Research Institute of Viticulture and Winemaking “Magarach”, 298600, 31 Kirov St., Yalta, Russian Federation
}

\begin{abstract}
One of the ways to reduce the pesticidal burden in mature ampelocenoses is the use of foliar biopreparations of multifunctional action. We studied the influence of growth bioregulators "Albit" and "MivalAgro" at reduced by 25-50\% fungicidal load on productivity and phenolic complex composition (using the HPLC method) of Vitis vinifera "Asma" (Crimean autochthonous table cultivar), "Cabernet Sauvignon" and table grapes of complex genetic structure "Moldova", grown in the mountain-valley seaside region of Crimea. It was established that bio-regulators increase the harvest of grapes, especially in the first and third years of treatment, depending on the preparation and grape cultivar, by $27-64 \%$ and $24-29 \%$, respectively, as compared to control; the bunch weight increased by $134 \pm 41 \%$. The first two years of treatment enhance sugar accumulation in berries by 0.7-2.6 Brix. "Albit" preparation proved to be more effective as compared to "Mival-Agro". The use of "Albit" on "Moldova" and "Cabernet Sauvignon" grapes increased components content in the berries by $19 \%-88 \%$ relative to control, depending on the cultivar and year of treatment, of which: anthocyanins - by $23-83 \%$, stilbenes - by $24-138 \%$. Regardless of treatment, the anthocyanin complex consisted by 75-87\% of malvidin monoglucosides in "Cabernet Sauvignon" and "Asma"; $22-56 \%$ of malvidin monoglucosides and 21-62\% of malvidin diglucoside in "Moldova". The studied preparations had no significant impact on the quality of wines from "Cabernet Sauvignon", however, they improved the quality of table grapes and their preservation capacity during storage.
\end{abstract}

\section{Introduction}

The intensive farming practices adopted in the world practice since the mid-20th century with the aim of increasing the crop yields include the widespread application of chemical agents to provide plants with nutrients and protect them against pests, diseases, and weeds. Agricultural production is a global factor in adverse impact on the biosphere: mineral fertilizers and pesticides are amongst the top 10 most dangerous pollutants of the natural environment. Due to their high biological activity, pesticides lead to changes in the soil microbiocenosis, pose a threat to biodiversity and human health due to the accumulation of pesticides in food chains [1-3]. The issues addressing the rational use of soil resources and reduced pesticidal burden in mature ampelocenoses are particularly relevant in viticulture, being a monoculture. One effective way of addressing this problem is to stimulate plant's own defense system by introducing mineral nutrition elements in the form of foliar biopreparations of multifunctional action $[4,5]$.

This generates a considerable scientific and practical interest in the development of new foliar preparations of biological origin, optimization of their composition, timing, doses and methods of application [6,7]. Using the vineyards of Crimea as an example, N.V. Aleinikova et al. demonstrated that it is possible to reduce the frequency of treatment and rates of chemical pesticides application during one treatment (by 30\%) without reducing their biological effectiveness against major malevolent objects due to the rational use of multifunctional bio-preparations [7].

Bioregulators acting at the level of cellular structures reduce the influence of biotic and abiotic stresses, increasing grape productivity, bunch weight, and improving the uvological characteristics. A number of researchers have registered reduced berry ripening period and improved harvest quality indicators [8-10].

A.E. Mario et al. [10] observed polyphenol accumulation, incl. anthocyanins, in grapes when bio-regulators were applied. L. Salvi et al. [11] demonstrated that the use of foliar biostimulants based on seaweed extracts and one vegetal protein hydrolysate helped improve the balance between technological and phenolic maturities, basically by maintaining the berries sugar content and by increasing their anthocyanin and polyphenol contents. Phenolic compounds, being secondary metabolites, play a significant role in grape resistance to phytopathogens and stressful environmental influences [12]. The phenolic complex is involved in formation of quality and antioxidant activity of grape and wines $[13,14]$. In the case of table grapes, the use of biopreparations as foliar dressing decreased the level of natural mass wastage of grapes during storage [15].

The effectiveness of a particular biostimulant in terms of harvest quantitative and qualitative indicators largely

(C) The Authors, published by EDP Sciences. This is an Open Access article distributed under the terms of the Creative Commons Attribution License 4.0 (http://creativecommons.org/licenses/by/4.0/). 
depends on the grape cultivar and soil and climatic conditions of its growth $[9,10]$.

This paper studied the effects of growth bioregulators "Albit" and "Mival-Agro", in conditions of reduced fungicidal burden, on productivity and phenolic complex composition of grapes grown in Crimea.

\section{Materials and methods}

\subsection{Foliar biopreparations}

The following preparations were used in the study: "Albit" (NPO Albit, Russian Federation) and "Mival-Agro" (OOO Agrosil, Russian Federation). "Albit" is a growth regulator of biological origin, the main active ingredient of which is poly- $\beta$-hydroxybutyric acid from soil bacteria Bacillus megaterium. The preparation comprises potassium nitrate, potassium phosphate (ortho) disubstituted, carbamide, magnesium sulfate. The mechanism of action of "Albit" is based on interaction with NADPH-oxidase system receptors of plants, which stimulates the expression of a complex of antioxidant enzymes. The "Albit" treated plants acquire increased resistance to pesticidal stress, drought, extreme temperatures, salinization, and other stresses; the preparation contributes to harvest preservation and higher yields [16]. "Mival-Agro" is a bio-silicon containing organic plant growth regulator, consisting of 2 components: mival (1-chloromethylsilatran - organosilicon compound from the group of silatranes) and crezatin (triethanolammonium salt of ortho-creoxyacetic acid phytohormone analogue from the auxin group). It has a wide range of biological effects, adaptogenic and antioxidant properties, and is environmentally friendly. By intensifying the vital processes, "Mival-Agro" strengthens plant protective properties, improves their resistance to adverse conditions and increases productivity [16].

\subsection{Growth conditions and grape treatment scheme}

The studies were conducted in 2015-2017 years on Vitis vinifera grapes "Asma" (Crimean autochthonous table cultivar), "Cabernet Sauvignon" and table grapes of complex genetic structure "Moldova" growing in the mountain-valley seaside region of Crimea (v. Morskoye, industrial-agrarian association "Massandra"). The studied grape culture was uncovered. The planting scheme for table grapes was $3.0 \times 1.5 \mathrm{~m}$. The bush form was a threebranch fan-shaped vine. The training system was vertical trellis.

The protection scheme adopted at the entreprise (control) involves 10 treatments with chemical agents of various effects. The trial scheme (the experiment) involved additional 4-time foliar treatment of the grapes with "Albit" or "Mival-Agro" preparations in the following plant development phases: "growth of shoots and inflorescences" (phase of the 3-5 leaf), "before bloom", "the onset of berry growth and formation" and "veraison" (one month before harvesting). The rate of "Albit" in each treatment was $200 \mathrm{ml} / \mathrm{ha}$, that of "Mival-Agro" was $15 \mathrm{~g} / \mathrm{ha}$. During treatments with the tested preparations, the fungicidal load on grapes was reduced in line with the protocol presented in Table 1 .
Table 1. Protocol for introduction of protection chemicals of fungicidal action in treatment of grapes with bioregulators.

\begin{tabular}{|l|c|}
\hline $\begin{array}{l}\text { Periods of treatment with } \\
\text { "Mival-Agro" and "Albit" }\end{array}$ & $\begin{array}{l}\text { Chemical treatment with } \\
\text { fungicides, \% of the } \\
\text { recommended rate }\end{array}$ \\
\hline \multicolumn{2}{|c|}{ "Asma", "Moldova" cultivars } \\
\hline $\begin{array}{l}\text { growth of shoots and } \\
\text { inflorescences } \\
\text { (phase of the 3-5 leaf) }\end{array}$ & was not conducted \\
\hline before bloom & $75 \%$ \\
\hline $\begin{array}{l}\text { the onset of berry growth and } \\
\text { formation }\end{array}$ & $75 \%$ \\
\hline veraison & $75 \%$ \\
\hline \multicolumn{2}{|c|}{ "Cabernet Sauvignon" cultivar } \\
\hline $\begin{array}{l}\text { growth of shoots and } \\
\text { inflorescences } \\
\text { (phase of the 3-5 leaf) }\end{array}$ & was not conducted \\
\hline before bloom & $75 \%$ \\
\hline $\begin{array}{l}\text { the onset of berry growth } \\
\text { and formation }\end{array}$ & $50 \%$ \\
\hline \begin{tabular}{l} 
veraison \\
\hline
\end{tabular} & $50 \%$ \\
\hline
\end{tabular}

\subsection{Sample preparation, determination of grape productivity indicators, chemical and HPCL analysis of grapes}

Productivity and quality of grapes were assessed on 20 reference bushes ( 4 replications of 5 plants) in control and experimental treatment options. We measured the number of bunches per bush, bunch weight, and the yield.

A bulk sample of berries from five bushes of each replication from control and test variants was selected for chemical and HPCL analyses. The sample weight was about $1000 \mathrm{~g}$, of which 300-350 g were used to determine grape quality indicators, the rest were used to analyze berry phenolic complex by HPLC.

To determine the content of sugars and titratable acids, the berries were crushed in a turbo blender (Moulinex - LM600E, France); juice suspension was centrifuged at $5000 \mathrm{rpm}$ (Sigma 4K10 Braun, Germany) for $15 \mathrm{~min}$; the juice was filtered through $0.45 \mu \mathrm{m}$ pore size membrane filters. Total sugars were determined by areometric method, titrated acids in terms of tartaric acid were determined by titrimetric method.

To analyze berry phenolic complex by HPLC, skins, pulp and seeds were ground in a mortar; homogenates were poured with an extractant $(50 \%$ methanol solution on a $0.5 \%$ aqueous solution of hydrochloric acid) in the ratio of $1: 4$ and kept at a temperature of $3-5^{\circ} \mathrm{C}$ for 5 days. The obtained extracts were centrifuged at $3000 \mathrm{rpm}$ for $5 \mathrm{~min}$. The supernatant was used for analysis on the HPLC system Shimadzu LC20 Prominence (Japan), equipped with a spectrophotometric detector with a diode matrix of the ultraviolet and visible ranges. To separate phenolic components, a Nucleosil C18AB column (Macherey - Nagel, Germany) $250 \mathrm{~mm}$ long, $2.0 \mathrm{~mm}$ in diameter was used filled with reversedphase sorbent. The injected sample volume was $2 \mu \mathrm{L}$. Elution was carried out in a gradient mode of increasing 
Table 2. Productivity and quality indicators (arithmetic mean value $\pm \mathrm{SD}$ ) of grapes processed by control and trial schemes.

\begin{tabular}{|c|c|c|c|c|c|c|c|}
\hline $\begin{array}{c}\text { Treatment } \\
\text { variant }\end{array}$ & $\begin{array}{l}\text { Treatment, } \\
\text { year }\end{array}$ & $\begin{array}{l}\text { Bunch, } \\
\text { item per bush }\end{array}$ & $\begin{array}{c}\text { Bunch } \\
\text { weight, } g\end{array}$ & $\begin{array}{l}\text { Harvest, } \\
\text { kg per bush }\end{array}$ & $\begin{array}{c}\text { Total sugars, } \\
\text { Brix }\end{array}$ & $\begin{array}{c}\text { Titrated } \\
\text { acids, } \mathrm{gL}^{-1}\end{array}$ & $\begin{array}{c}\text { Tasting } \\
\text { assessment, point* }\end{array}$ \\
\hline \multicolumn{8}{|c|}{ "Cabernet Sauvignon" cultivar } \\
\hline control & \multirow{2}{*}{ the first } & $\mathbf{2 5 . 0} \pm 2.1$ & $\mathbf{8 4 . 5} \pm 7.9$ & $\mathbf{2 . 1} \pm 0.2$ & $19.2 \pm 1.2$ & $7.5 \pm 0.7$ & - \\
\hline "Albit" & & $\mathbf{2 0 . 0} \pm 2.2$ & $\mathbf{1 5 5 . 8} \pm 12.3$ & $\mathbf{3 . 1} \pm 0.2$ & $21.8 \pm 1.1$ & $7.0 \pm 0.6$ & - \\
\hline control & \multirow{2}{*}{ the second } & $\mathbf{3 7 . 4} \pm 3.3$ & $121.0 \pm 12.5$ & $4.5 \pm 0.6$ & $18.6 \pm 0.7$ & $8.2 \pm 0.6$ & - \\
\hline "Albit" & & $39.6 \pm 4.0$ & $\mathbf{1 2 6 . 0} \pm 13.1$ & $\mathbf{5 . 0} \pm 0.6$ & $20.2 \pm 1.4$ & $7.9 \pm 0.6$ & - \\
\hline control & \multirow{2}{*}{ the third } & $19.7 \pm 2.0$ & $\mathbf{7 9 . 0} \pm 9.3$ & $\mathbf{1 . 6} \pm 0.2$ & $19.9 \pm 1.3$ & $6.9 \pm 0.5$ & - \\
\hline "Albit" & & $24.9 \pm 2.5$ & $\mathbf{7 8 . 0} \pm 8.6$ & $\mathbf{1 . 9} \pm 0.3$ & $\mathbf{1 8 . 8} \pm 1.4$ & $\mathbf{8 . 6} \pm 0.4$ & - \\
\hline control & \multirow{2}{*}{ the first } & $21.0 \pm 2.5$ & $\mathbf{1 4 7 . 9} \pm 15.3$ & $\mathbf{3 . 1} \pm 0.3$ & $\mathbf{2 3 . 4} \pm 0.9$ & $7.9 \pm 0.6$ & - \\
\hline "Mival-Agro" & & $28.3 \pm 3.0$ & $\mathbf{1 7 2 . 1} \pm 18.1$ & $4.9 \pm 0.6$ & $24.7 \pm 1.2$ & $\mathbf{7 . 8} \pm 0.5$ & - \\
\hline control & \multirow{2}{*}{ the second } & $\mathbf{3 7 . 4} \pm 3.3$ & $\mathbf{1 2 1 . 0} \pm 12.5$ & $4.5 \pm 0.6$ & $18.6 \pm 0.7$ & $8.2 \pm 0.6$ & - \\
\hline "Mival-Agro" & & $37.2 \pm 3.0$ & $\mathbf{1 3 4 . 0} \pm 12.9$ & $\mathbf{5 . 0} \pm 0.8$ & $\mathbf{1 8 . 3} \pm 1.2$ & $\mathbf{8 . 2} \pm 0.8$ & - \\
\hline \multicolumn{8}{|c|}{ "Moldova" cultivar } \\
\hline control & \multirow{2}{*}{ the first } & $\mathbf{1 6 . 0} \pm 1.5$ & $\mathbf{3 7 3 . 4} \pm 36.8$ & $\mathbf{5 . 8} \pm 0.7$ & $\mathbf{1 7 . 1} \pm 1.5$ & $\mathbf{7 . 0} \pm 0.3$ & $\mathbf{6 . 6} \pm 0.4$ \\
\hline "Albit" & & $\mathbf{1 8 . 0} \pm 1.3$ & $408.0 \pm 41.2$ & $\mathbf{7 . 4} \pm 0.8$ & $\mathbf{1 7 . 4} \pm 1.4$ & $6.9 \pm 0.4$ & $8.1 \pm 0.5$ \\
\hline control & \multirow{2}{*}{ the second } & $\mathbf{2 2 . 9} \pm 2.6$ & $258.0 \pm 29.7$ & $\mathbf{5 . 9} \pm 0.6$ & $\mathbf{1 6 . 4} \pm 1.3$ & $\mathbf{6 . 8} \pm 0.5$ & $7.8 \pm 0.5$ \\
\hline "Albit" & & $\mathbf{1 3 . 6} \pm 1.5$ & $481.0 \pm 40.8$ & $\mathbf{6 . 5} \pm 0.8$ & $\mathbf{1 7 . 5} \pm 1.3$ & $\mathbf{6 . 0} \pm 0.6$ & $8.2 \pm 0.4$ \\
\hline control & \multirow{2}{*}{ the third } & $\mathbf{2 6 . 4} \pm 2.9$ & $273.0 \pm 32.1$ & $7.2 \pm 0.9$ & $23.1 \pm 1.2$ & $\mathbf{5 . 7} \pm 0.6$ & $8.2 \pm 0.3$ \\
\hline "Albit" & & $\mathbf{3 0 . 2} \pm 3.2$ & $\mathbf{3 1 3 . 0} \pm 31.3$ & $\mathbf{9 . 3} \pm 1.0$ & $\mathbf{2 2 . 8} \pm 1.2$ & $\mathbf{6 . 1} \pm 0.4$ & $\mathbf{8 . 9} \pm 0.3$ \\
\hline control & \multirow{2}{*}{ the first } & $\mathbf{1 5 . 0} \pm 1.7$ & $\mathbf{4 0 3 . 0} \pm 35.9$ & $6.3 \pm 0.5$ & $\mathbf{1 8 . 3} \pm 1.1$ & $\mathbf{5 . 6} \pm 0.6$ & $6.7 \pm 0.5$ \\
\hline "Mival-Agro" & & $\mathbf{1 8 . 4} \pm 1.6$ & $\mathbf{5 0 4 . 1} \pm 51.1$ & $\mathbf{9 . 3} \pm 0.9$ & $\mathbf{1 9 . 6} \pm 0.9$ & $\mathbf{5 . 6} \pm 0.7$ & $7.6 \pm 0.2$ \\
\hline control & \multirow{2}{*}{ the second } & $\mathbf{2 2 . 9} \pm 1.4$ & $\mathbf{2 5 8 . 0} \pm 29.7$ & $\mathbf{5 . 9} \pm 1.8$ & $\mathbf{1 6 . 4} \pm 1.5$ & $\mathbf{6 . 8} \pm 0.5$ & $7.8 \pm 0.5$ \\
\hline "Mival-Agro" & & $\mathbf{1 0 . 9} \pm 0.9$ & $\mathbf{5 9 5 . 0} \pm 53.7$ & $\mathbf{6 . 5} \pm 1.1$ & $\mathbf{1 8 . 0} \pm 1.2$ & $7.5 \pm 0.6$ & $\mathbf{8 . 7} \pm 0.3$ \\
\hline \multicolumn{8}{|c|}{ "Asma" cultivar } \\
\hline control & \multirow{2}{*}{ the first } & $\mathbf{8 . 0} \pm 1.0$ & $\mathbf{6 5 5 . 6} \pm 53.9$ & $\mathbf{5 . 3} \pm 0.4$ & $\mathbf{1 7 . 7} \pm 0.9$ & $\mathbf{6 . 5} \pm 0.7$ & $\mathbf{8 . 0} \pm 0.6$ \\
\hline "Albit" & & $\mathbf{1 2 . 4} \pm 0.9$ & $701.6 \pm 70.0$ & $\mathbf{8 . 7} \pm 0.9$ & $18.2 \pm 0.9$ & $\mathbf{6 . 4} \pm 0.4$ & $9.2 \pm 0.3$ \\
\hline control & \multirow{2}{*}{ the second } & $10.6 \pm 2.0$ & $759.3 \pm 84.7$ & $\mathbf{7 . 9} \pm 0.7$ & $\mathbf{1 7 . 5} \pm 1.3$ & $\mathbf{9 . 1} \pm 0.7$ & $\mathbf{8 . 1} \pm 0.7$ \\
\hline "Albit" & & $\mathbf{1 2 . 0} \pm 1.0$ & $\mathbf{7 6 4 . 4} \pm 80.1$ & $9.2 \pm 1.2$ & $\mathbf{1 9 . 5} \pm 1.1$ & $\mathbf{6 . 0} \pm 0.5$ & $\mathbf{8 . 6} \pm 0.8$ \\
\hline
\end{tabular}

* Tasting assessment by a 10-point rating scale.

the proportion of solution $\mathrm{B}\left(\mathrm{AcCN}\right.$ : $\mathrm{MeOH}: \mathrm{HClO}_{4}$ mixture in a ratio of 40:40:20, $\mathrm{pH} 2.5$ ) in a mixture with solution $\mathrm{A}$ (an aqueous solution of $\mathrm{HClO}_{4}, \mathrm{pH}$ 1.8) for 80 minutes. Chromatograms were recorded with a scan rate of $3 \mathrm{~Hz}$ at the following wavelengths: $280 \mathrm{~nm}$ - for gallic acid, (+)-D-catechin, (-)-epicatechin and procyanidins; $310 \mathrm{~nm}$ for hydroxycinnamic acids; $320 \mathrm{~nm}$ - for stilbenes; $330 \mathrm{~nm}$ - for derivatives of quercetin; $525 \mathrm{~nm}$ - for anthocyanins. The substances were identified by comparing their spectral characteristics and retention time with similar characteristics of the standards: caffeic and gallic acids, (+)-D-catechin, quercetin dehydrate, malvidin-3-O-glucoside chloride, malvidin-3O-diglycoside, trans-resveratrol (Fluka Chemie AG, Switzerland) and (-)-epicatechin (Sigma-Aldrich, Switzerland). The concentration of phenolic components was determined by calibration graphs reflecting the dependence of the peak area on concentration of standard substances, using the LC Solutions (Shimadzu) program. The total content of phenolic compounds in the berries was calculated taking into account the mass fraction of the skin, pulp and seeds in the berries.

\subsection{Grape storage technology, winemaking and quality assessment of objects}

Wine sample preparation from "Cabernet Sauvignon" grapes was done in the conditions of micro-vinification. The technology involved: grape crushing with crest separation; introduction of sulfur dioxide into the pulp $\left(80 \pm 5 \mathrm{mg} \mathrm{L}^{-1}\right)$ and Saccharomyces cerevisiae yeast (strain I-25 from the Collection of Microorganisms for Winemaking of the Institute "Magarach"); pulp fermentation at $25 \pm 3{ }^{\circ} \mathrm{C}$ in a glass container; pulp fermentation up to $2 / 3$ of residual sugars from the initial values; pulp pressing in a basket press; must fermentation, autoclarification and wine decantation. The wine was stored in glass containers without aeration in the dark at $12-14{ }^{\circ} \mathrm{C}$ for 2 months, after which the wine was tasted and analyzed. The wine samples were measured 
for the following: alcohol content by volume (by the distillate relative density), $\mathrm{pH}$, concentration of titrated (in terms of tartaric acid) and volatile acids, reducing sugars (titrimetrie), total extract [17], phenolic compounds using Folin-Ciocalteu reagent [18]. In organoleptic analysis, the quality of wines was assessed by an 8-point scale.

Table grapes were stored in a refrigerating chamber of $20 \mathrm{~m}^{3}$ equipped with cooled air convective supply, and inflow exhaust ventilation for 150 days. At the end of storage, the organoleptic indicators of grapes were evaluated by a 10-point scale, the natural wastage and standard product output were determined.

\subsection{Data statistical analysis}

All chemical and HPLC analyses were performed in triplicate. The data were mathematically processed with the help of statistical software package SPSS Statistics 17.0. Arithmetic mean value, variance of a single result and standard deviation (SD) were determined. Statistically significant differences of grape indicators processed according to control and experimental schemes were identified based on Mann-Whitney (U-test) criterion. The predetermined probability of an erroneous result (p) was less than 0.05 .

\section{Results and discussion}

The yield of the studied grape cultivars in the control treatment variants $(100 \%$ of the pesticidal load) was on average (kg per bush): “Cabernet Sauvignon” - 1.6-4.5; "Moldova" - 5.8-7.2; "Asma” - 5.3-7.9 (Table 2).

The data in Table2 shows that under conditions of reduced fungicidal load the effect of growth bioregulators on the harvest was most pronounced in the first year of treatment: the harvest increased by $27-64 \%$ depending on the preparation and grape cultivar, as compared to control. The greatest increase in the yield was observed when "Asma" grape were treated with "Albit" preparation the yield increased from 5.3 to $8.7 \mathrm{~kg}$ per bush. "Mival-Agro" worked best on "Cabernet Sauvignon" grapes - the yield increased on average by $56 \%$ (from 3.1 to $4.9 \mathrm{~kg}$ per bush). In the second year of treatment with the preparations, the increase in the yield made 10$16 \%$ as compared to the control: there was no significant difference in the yield increase depending on grape cultivar and the preparation used. In the third year of treatment, the efficiency of "Albit" preparation increased; thus, for "Moldova" grapes, the yield increase was at the level of the first year, and reached $29 \%$ as compared to the control. For "Cabernet Sauvignon" grapes, the yield increase made $24 \%$, which was 2 times less than in the first year of treatment.

After treatment with bio-regulators, the yield increased mainly due to an increase in the bunch weight, which was observed in $93 \%$ of cases: the bunch weight in the trial variants was $134 \pm 41 \%$, as compared to the index value in the control batches of grapes. The smallest increase in the indicator in the course of 2-year studies was observed on "Asma" grapes treated with "Albit" - the yield increase made on average 5\%; the highest increase was received in the second year of treatment of "Moldova" grapes with "Mival-Agro" (131\%). In the case of "Cabernet Sauvignon" grapes, the bunch weight decreased from the

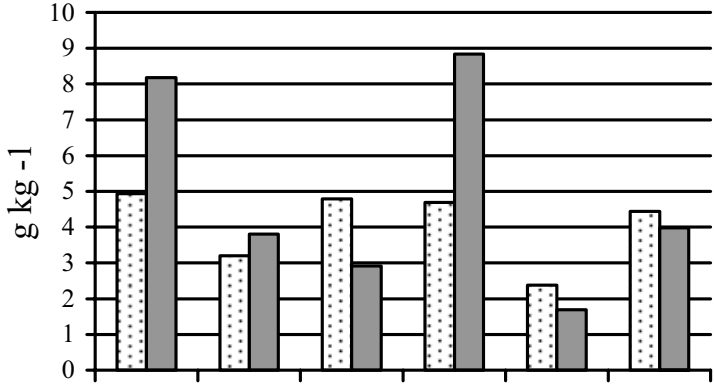

CS 1 Mol 1 Mol 2 Mol 3 As 1 As 2

$\square$ Control $\square$ "Albit"

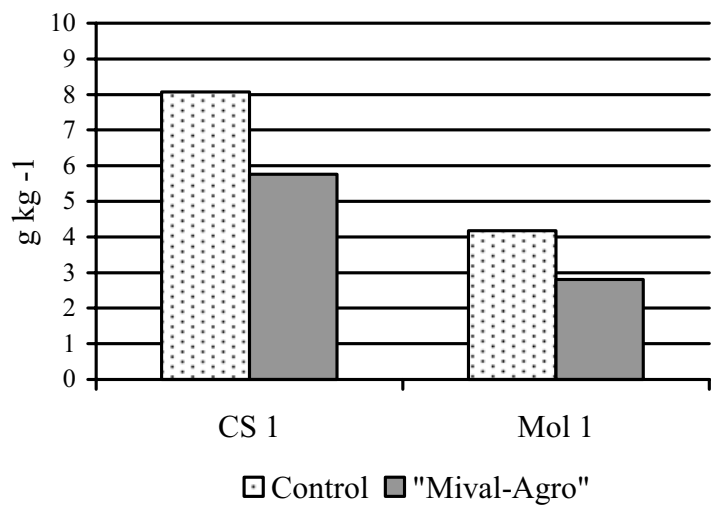

Figure 1. The phenolic compounds content in grapes processed using the control and experimental variants: arithmetic mean value, SD-values were lower than $10 \%$ for all assays; CS "Cabernet Sauvignon", Mol - "Moldova", As - "Asma"; 1, 2, 3 - year of treatment.

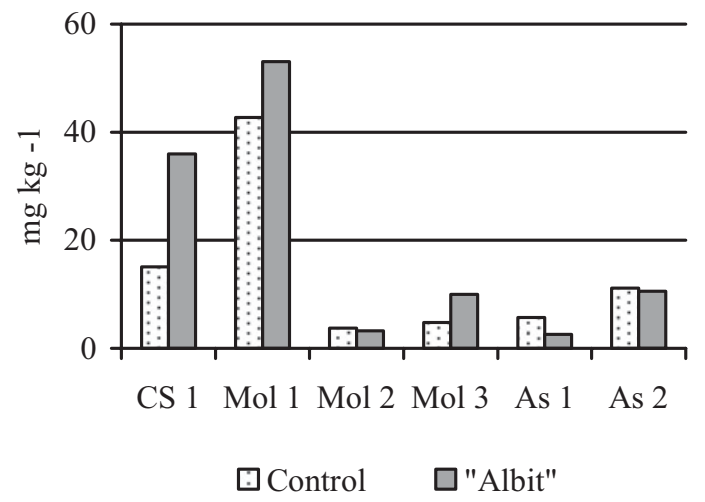

Figure 2. The stilbene content in the grapes treated by various schemes: arithmetic mean value, SD-values were lower than $10 \%$ for all assays; CS - "Cabernet Sauvignon", Mol - "Moldova", As - "Asma"; 1, 2, 3 - year of treatment.

first to the third year of treatment with "Albit" from $87 \%$ to $0 \%$.

Sugar content in the grapes of the control treatment variants during harvest period was 16.4-23.4 Brix, that of titrated acids made $5.6-9.1 \mathrm{~g} \mathrm{~L}^{-1}$ (Table 2). In the first two years of grape treatment with growth bioregulators, the sugar content remained at the level of control variants or increased by $0.7-2.6$ Brix: the greatest increase in the indicator values was observed during treatment of "Cabernet Sauvignon" and "Asma” grapes with "Albit" (2.6 Brix and 2.0 Brix respectively). In the third year of "Albit" application, sugar content in 
Table 3. The content ${ }^{1}\left(\mathrm{mg} \mathrm{kg}^{-1}\right)$ of mono- and diglucosides of cyanidin, delphinidin, petunidin, peonidin, malvidin and their derivatives in berries of grapes treated according to control and trial variants.

\begin{tabular}{|c|c|c|c|c|c|c|c|}
\hline $\begin{array}{c}\text { Treatment } \\
\text { variant }\end{array}$ & Year & Cyanidin & Delphinidin & Petunidin & Peonidin & $\begin{array}{l}\text { Malvidin- } \\
\text { glycoside }\end{array}$ & $\begin{array}{l}\text { Malvidin- } \\
\text { diglucoside }\end{array}$ \\
\hline \multicolumn{8}{|c|}{ "Cabernet Sauvignon" cultivar } \\
\hline control & \multirow{2}{*}{ the first } & 37.6 & 448.3 & 259.2 & 130.4 & 3021.2 & 11.6 \\
\hline "Albit" & & 79.9 & 688.7 & 467.7 & 223.6 & 5673.4 & 14.8 \\
\hline control & \multirow{2}{*}{ the first } & 48.4 & 120.9 & 411.8 & 253.6 & 5627.1 & 0 \\
\hline "Mival-Agro" & & 139.9 & 124.3 & 416.2 & 335.1 & 2980.8 & 0 \\
\hline \multicolumn{8}{|c|}{ "Moldova" cultivar } \\
\hline control & \multirow{2}{*}{ the first } & 5.7 & 130.8 & 267.3 & 71.3 & 574.8 & 1510.4 \\
\hline "Albit" & & 4.9 & 200.1 & 276.8 & 35.2 & 936.7 & 1708.2 \\
\hline control & \multirow{2}{*}{ the second } & 71.9 & 680.1 & 2.0 & 105.2 & 1608.7 & 732.4 \\
\hline "Albit" & & 31.4 & 382.7 & 0.7 & 58.3 & 1110.0 & 433.8 \\
\hline control & \multirow{2}{*}{ the third } & 76.0 & 726.5 & 2.5 & 116.2 & 1765.4 & 810.3 \\
\hline "Albit" & & 130.6 & 1161.5 & 3.1 & 3.4 & 3019.9 & 1330.4 \\
\hline control & \multirow{2}{*}{ the first } & 4.2 & 49.5 & 301.1 & 159.4 & 814.5 & 2003.0 \\
\hline "Mival-Agro" & & 3.3 & 26.6 & 183.2 & 89.3 & 538.8 & 1428.7 \\
\hline \multicolumn{8}{|c|}{ "Asma" cultivar } \\
\hline control & \multirow{2}{*}{ the first } & 26.8 & 85.6 & 103.4 & 210.6 & 1528.0 & 0 \\
\hline "Albit" & & 18.5 & 42.5 & 53.4 & 175.9 & 1015.4 & 0 \\
\hline control & \multirow{2}{*}{ the second } & 38.9 & 87.8 & 121.2 & 337.9 & 1813.8 & 0.5 \\
\hline "Albit" & & 31.5 & 74.0 & 104.3 & 211.5 & 1655.8 & 0.2 \\
\hline
\end{tabular}

${ }^{1}$ Arithmetic mean value, SD-values were lower than $10 \%$ for all assays.

"Cabernet Sauvignon" grapes decreased by 1.1 Brix, in "Moldova" grapes it remained at the level of control. The change in the content of titratable acids in grapes under the influence of the studied preparations, in most cases, did not exceed $0.8 \mathrm{~g} \mathrm{~L}^{-1}$.

The HPLC analysis determined content of phenolic acids, flavonols, flavan-3-ol monomers, procyanidins $\mathrm{B}_{1}-\mathrm{B}_{8}$, anthocyanins and stilbenes in the grapes. The total content of identified phenolic compounds in berries of the grapes processed by the control scheme varied within the ranges: "Cabernet Sauvignon" - 4926-8071 $\mathrm{mg} \mathrm{kg}^{-1}$; "Moldova" - 3023-5424 mg kg ${ }^{-1}$; “Asma” - 2377$4437 \mathrm{mg} \mathrm{kg}^{-1}$. In the first year of "Cabernet Sauvignon" and "Moldova' grapes treatment with "Albit", there was an increase in the total content of phenolic compounds in the berries by an average of $66 \%$ and $19 \%$, respectively, as compared to control (Fig. 1). In the second year, application of "Albit" to "Moldova" grapes led to a $39 \%$ decrease in the content of phenolic components in the berries, as compared to the values of this indicator in the grapes treated by control schemes; in the third year, however, the values increased by $88 \%$. When "Asma" grapes were treated with "Albit", and "Cabernet Sauvignon" and "Moldova" cultivars were treated with "Mival-Agro", the phenolic compounds content decreased by $13-33 \%$, as compared to the control.

The change in the total content of phenolic compounds in grapes under the effect of foliar dressings is mainly due to the quantitative changes in the anthocyanin complex (Table 3). Mono- and diglucosides of malvidin, delphinidin, cyanidin, peonidin, petunidin and their derivatives acylated by acetic acid or by $\mathrm{p}$ coumaric acid were identified in the anthocyanin complex of the berries. Regardless of the treatment scheme applied in the vineyards, the anthocyanin complex of "Cabernet Sauvignon" and "Asma" grapes was up to $75-87 \%$ comprised of malvidin-3-O- $\beta$-D-glucoside and its derivatives, which is characteristic of the anthocyanin compounds transformation process of Vitis vinifera [20]. Monoglucosides of malvidin accounted for $22-56 \%$, and diglucoside of malvidin $-21-62 \%$ in the grapes of a complex genetic structure "Moldova". Under the influence of "Albit" the increase in the anthocyanin complex content in "Cabernet Sauvignon" and "Moldova" grape cultivars averaged $83 \%$ and $23 \%$ as compared to control in the first year of treatment, and in the third year it averaged 62\% ("Moldova" cultivar). In the second year of treatment with "Albit", the decrease in the anthocyanin content of "Moldova" grapes averaged 37\%, in "Asma" grapes this indicator decreased from $31 \%$ in the first year of treatment to $13 \%$ in the second year. When "Cabernet Sauvignon" and "Moldova" grapes were treated with "Mival-Agro", there was observed a $32-38 \%$ decrease in the anthocyanin complex content as compared to the control. Among stilbenes that play an important role in phyto-immunity, trance- and cisresveratrol and their dimeric forms ( $\varepsilon$ - and $\alpha$-viniferin) were identified in the grapes. The stilbene content in the "Cabernet Sauvignon" grapes treated by control scheme ranged from 13.4 to $16.5 \mathrm{mg} \mathrm{kg}^{-1}$, in "Moldova" 
Table 4. The effect of foliar dressing on the quality of grapes during long-term storage, mean over 2 years.

\begin{tabular}{|l|c|c|c|c|}
\hline Cultivar & $\begin{array}{c}\text { Tratement } \\
\text { variant }\end{array}$ & $\begin{array}{c}\text { Tasting } \\
\text { assessment, } \\
\text { point }\end{array}$ & $\begin{array}{c}\text { Natural } \\
\text { bunch weight } \\
\text { wastage, \% }\end{array}$ & $\begin{array}{c}\text { The output } \\
\text { of standard } \\
\text { product, \% }\end{array}$ \\
\hline "Moldova" & control & 6.7 & 7.4 & 92.3 \\
\cline { 2 - 5 } & "Albit" & 7.7 & 6.5 & 93.5 \\
\cline { 2 - 5 } & control & 7.2 & 9.0 & 91.0 \\
\cline { 2 - 5 } & "Mival-Agro" & 7.9 & 9.2 & 90.8 \\
\hline "Asma" & control & 6.0 & 5.3 & 94.7 \\
\cline { 2 - 5 } & "Albit" & 7.5 & 4.1 & 95.9 \\
\hline
\end{tabular}

Table 5. Physico-chemical parameters and sensory assessment (arithmetic mean value ${ }^{1}$ ) of control and trial "Cabernet Sauvignon" wines.

\begin{tabular}{|l|c|c|c|c|c|}
\hline \multirow{2}{*}{ Indicator } & \multicolumn{4}{|c|}{ Harvest of 2016 } & \multicolumn{2}{|c|}{ Harvest of 2017 } \\
\cline { 2 - 6 } & \multicolumn{5}{|c|}{ Grape treatment variants } \\
\cline { 2 - 6 } & Control & "Albit" "Mival Agro" & Control & "Albit" \\
\hline Alcohol, \% & 12.5 & 12.0 & 11.5 & 11.5 & 12.0 \\
\hline $\begin{array}{l}\text { Titrated } \\
\text { acids, g L }\end{array}$ & 8.0 & 8.2 & 8.4 & 6.3 & 6.9 \\
\hline $\begin{array}{l}\text { Volatile } \\
\text { acids, g L }\end{array}$ & 0.4 & 0.6 & 0.5 & 0.2 & 0.2 \\
\hline $\begin{array}{l}\text { Reducing } \\
\text { sugars, g L }\end{array}$ & 4.0 & 5.0 & 5.0 & 1.1 & 1.2 \\
\hline $\begin{array}{l}\text { Total extract, } \\
\text { g L }\end{array}$ & 29.5 & 28.8 & 32.5 & 23.2 & 22.3 \\
\hline $\begin{array}{l}\text { Phenolic } \\
\text { compounds, } \\
\text { mg L }\end{array}$ & 1745 & 1700 & 1642 & 2105 & 2164 \\
\hline pH & 3.2 & 3.3 & 3.1 & 3.5 & 3.4 \\
\hline $\begin{array}{l}\text { Tasting } \\
\text { assessment, } \\
\text { points }\end{array}$ & 7.77 & 7.74 & 7.69 & 7.67 & 7.65 \\
\hline
\end{tabular}

${ }^{1} \mathrm{SD}$-values were lower than $5 \%$ for all assays.

- from 4.8 to $44.0 \mathrm{mg} \mathrm{kg}^{-1}$, and in "Asma"-from 5.7 to $11.2 \mathrm{mg} \mathrm{kg}^{-1}$. Treatment of "Cabernet Sauvignon" and "Moldova" cultivars with "Albit" in the first year was accompanied by increased accumulation of stilbenes in the berries (by $138 \%$ and $24 \%$ relative to the control), reaching an average of $36.0 \mathrm{mg} \mathrm{kg}^{-1}$ and $53.0 \mathrm{mg} \mathrm{kg}^{-1}$ (Fig. 2).

In the case of "Moldova" grapes, the effect from "Albit" application was repeated in the third year of treatment: an increase in the content of stilbenes made $108 \%$. When "Asma" grapes were treated with "Albit", the stilbene content in the berries decreased, particularly critically in the first year - by $41 \%$ relative to the control. A decrease in the components content (by 21\%) was recorded in the first year of treatment "Moldova" grapes with "Mival-Agro".

The use of "Albit" and "Mival-Agro" bio-regulators during all years of application to table grapes improved the sensory characteristics of fresh grapes: the tasting score increased by an average of 0.9 points (shown in Table 2) and remained high relative to control throughout the storage period (150 days). The use of "Albit" on "Moldova" cultivar reduced the natural weight loss during storage of table grapes from one year to the next on average by $12 \%$, which, in turn, contributed to an increase in the yield of standard product. In other variants of the assay, the natural loss of the bunch weight indicators and the output of standard products were comparable to that of the control (Table 4).

From control and trial batches of "Cabernet Sauvignon' of 2016 and 2017 harvests (second and third year of treatment) dry wines were prepared. The data in Table 5 suggests that grape treatment with bio-regulators during two or three years did not significantly affect the physicochemical and organoleptic characteristics of the wines. The wine samples obtained from grapes treated by control scheme and with application of "Albit" demonstrated a varietal aroma with berries and spices on the nose with shades of solanum transforming into taste that was fullbodied and balanced. The wines obtained from grapes treated with "Mival-Agro" had a muted berry aroma with grassy and candy overtones.

\section{Conclusion}

Application of biological methods in agriculture and stimulation of the plant's own immune system are topical areas aimed at reduction of the pesticidal burden on the biosphere. The comparison of the effect of foliar bioregulators of multifunctional action "Albit" and "MivalAgro" in conditions of a $25-50 \%$ lower fungicidal load on the quantitative and qualitative indicators of grape cultivars ("Asma", "Moldova", "Cabernet Sauvignon") suggest the following. Bioregulators increase the yield of grapes, especially in the first and third years of treatment, by $27-64 \%$ and $24-29 \%$ dependent on the preparation and grape cultivar, and increase the bunch weight by $134 \pm$ $41 \%$, as compared to the control. The first two years of treatment improve sugar accumulation in berries by $0.7-$ 2.6 Brix. The effectiveness of "Albit" preparation exceeds that of "Mival-Agro". Treatment of "Moldova" and "Cabernet Sauvignon" grapes with "Albit" preparation stimulated biosynthesis of phenolic compounds: their content in the berries increased by $19-88 \%$, as compared to control, depending on the cultivar and year of treatment, including anthocyanins - by $23-83 \%$, stilbenes - by 24-138\%.

The results indicate that "Albit" and "Mival-Agro" bio-regulators used in conditions of reduced fungicidal burden increased productivity and mobilized the protective mechanism of grapes. At the same time, growth bioregulators had no significant effect on the quality of young wines from "Cabernet Sauvignon" grapes, and improved the quality of table grapes and their preservation capacity during storage.

The authors want to thank all their colleagues for their assistance in the research for this paper.

\section{References}

[1] D. Tilman, C. Balzer, J. Hill, B.L. Befort, Proc. Natl. Acad. Sci. USA 108, 20260 (2011)

[2] M.E. Podgornaya, Fruit-growing and Viticulture of South of Russia 29, 96 (2014) 
[3] J. Rochard, C. Herbin, V. Lempereur, BIO Web of Conf. 7, 01026 (2016)

[4] P. Calvo, L. Nelson, J.W. Kloepper, Plant and Soil 383, 3 (2014)

[5] M.E. Garcia, D.A. Dickey, S.D. Frey, D.T. Johnson, Acta Hortic. (ISHS) 1115, 29 (2016)

[6] E.P. Stranishevskaya, Ya.A. Volkov, E.A. Matveikina, N.I. Shadura, "Magarach". Viticulture and Winemaking 4, 70 (2018)

[7] N.V. Aleinikova, E.S. Galkina, Ya.E. Radionovskaia, V.N. Shaporenko, "Magarach". Viticulture and Winemaking 4, 29 (2015)

[8] M. Colapietra, A. Alexander, Acta Hortic. 721, 213 (2006)

[9] A.G. Turmina, A.P.F. Lima, A.F. Fagherazzi, A.E. Mario, P.I. Mudrei, M.A. Andrião, L. Rufato, Acta Hortic. 1157, 429 (2017)

[10] A.E. Mario, F. Fagherazzi, A.G. Turmina, S. Lerin, D.S. de Souza, L. Rufato, M.A. Andriao, Acta Hortic. 1157, 367 (2017)

[11] L. Salvi, E.S. Cataldo, S. Secco, G.B. Mattii, Acta Hortic. 1148, 9 (2016)
[12] V. Cheynier, G. Comte, K.M. Davies, V. Lattanzio, S. Martens, PPB 72, 1 (2013)

[13] E. Ostroukhova, I. Peskova, M. Vyugina, S. Levchenko, Acta Hortic. 1205, 327 (2018)

[14] E.V. Ostroukhova, I.V. Peskova, P.A. Probeigolova, G.N. Verik, "Magarach". Viticulture and Winemaking 1, 30 (2012)

[15] S. Levchenko, A. Batukaev, V. Volynkin, V. Likhovskoi, I. Vasylyk, V. Boiko, D. Belash, Advances in Engineering Research (ISPC AgroSMART, Atlantis Press, 2018)

[16] S.V. Levchenko, E.V. Ostroukhova, I.A. Vasylyk, V.A. Boyko, N.Yu. Lutkova, Scientific works of the North Caucasus Regional Research Institute of Horticulture and Viticulture, 11, 99 (2016)

[17] Compendium of International Méthods of Wine and Must Analysis (O.I.V., Paris, 2018), p. 1

[18] V.G. Gerzhikova, Methods of Technochemical Control in Winemaking (Simferopol, Tavrida, 2009)

[19] L. Narduzzi, J. Stanstrup, F. Mattivi, J. Agric. Food Chem. 63, 6823 (2015) 